\title{
Insight into thermophiles and their wide-spectrum applications
}

\author{
Ridhi Mehta $^{1} \cdot$ Paavan Singhal $^{1} \cdot$ Hardeep Singh $^{1} \cdot$ Dhanashree Damle $^{2} \cdot$ \\ Anil K. Sharma ${ }^{1}$
}

Received: 29 August 2015/Accepted: 8 January 2016/Published online: 23 February 2016

(c) The Author(s) 2016. This article is published with open access at Springerlink.com

\begin{abstract}
The deconstruction of biomass is a pivotal process for the manufacture of target products using microbial cells and their enzymes. But the enzymes that possess a significant role in the breakdown of biomass remain relatively unexplored. Thermophilic microorganisms are of special interest as a source of novel thermostable enzymes. Many thermophilic microorganisms possess properties suitable for biotechnological and commercial use. There is, indeed, a considerable demand for a new generation of stable enzymes that are able to withstand severe conditions in industrial processes by replacing or supplementing traditional chemical processes. This manuscript reviews the pertinent role of thermophilic microorganisms as a source for production of thermostable enzymes, factors afftecting them, recent patents on thermophiles and moreso their wide spectrum applications for commercial and biotechnological use.
\end{abstract}

Keywords Thermophilic microorganisms .

Thermostable enzymes $\cdot$ Heat tolerance and biomass

\section{Introduction}

Organisms with an optimum temperature for growth between 60 and $80{ }^{\circ} \mathrm{C}$ are generally designated as thermophiles, while those growing optimally above $80{ }^{\circ} \mathrm{C}$ are

Anil K. Sharma

anibiotech18@gmail.com

1 Department of Biotechnology, M.M. University, Mullana, Ambala, Haryana 133207, India

2 Department of Orthodontics, M.M.Institute of Dental Sciences \& Research, M.M. University, Mullana, Ambala, Haryana 133207, India referred to as hyperthermophiles (Santos and Da Costa 2002). Thermophilic bacteria are microbes that mostly inhabit hot springs, live and survive in temperatures above $70{ }^{\circ} \mathrm{C}$. As a consequence of growth at high temperatures and unique macromolecular properties, thermophiles can possess high metabolism, physically and chemically stable enzymes and lower growth but higher end product yields than similar mesophilic species (Haki and Rakshit 2003) (Tables 1, 2).

Natural environments for anaerobic thermophiles range from terrestrial volcanic sites (including solfatara fields) with temperatures slightly above ambient temperature, to submarine hydrothermal systems (sediments, submarine volcanoes, fumaroles and vents) with temperatures exceeding $300{ }^{\circ} \mathrm{C}$, subterranean sites such as oil reservoirs, and solar heated surface soils with temperatures up to $65{ }^{\circ} \mathrm{C}$. There are also human-made hot environments such as compost piles (usually around $60-70{ }^{\circ} \mathrm{C}$ but as high as $100{ }^{\circ} \mathrm{C}$ ) slag heaps, industrial processes and water heaters (Oshima and Moriya 2008).

The ubiquitous nature of the thermophiles is attested to by the great variety of sources from which they have been isolated from freshly fallen snow (Golikowa 1926) to the sands of the Sahara Desert (Negre 1913). They have been found to occur in the air (Sames 1900), the soil of temperate (Blau 1906; Gilbert 1904; Sames 1900) and tropical (De Kruyff, 1910) regions, salt (MacFadyen and Blaxall 1896) and fresh water, both cold (Tirelli 1907; Catterina 1904) and thermal (Georgevitch 1910a, b; Falcioni 1907; Benignetm 1905; Setchell 1903).

Factors affecting heat tolerance of thermophilic organisms are as follows:

1. Permeability: cell membranes effectively function as a permeability barrier, controlling the in-flow and out-

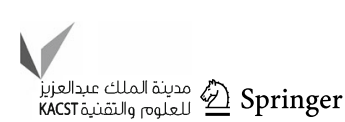


Table 1 Thermophilic enzymes and their potential roles

\begin{tabular}{|c|c|c|c|c|}
\hline Microorganisms & Enzymes & $\begin{array}{l}\text { Temperature of } \\
\text { activity }\end{array}$ & Applications & References \\
\hline Pyrococcus woesei & alpha-Amylases & Topt. $=100{ }^{\circ} \mathrm{C}$ & $\begin{array}{l}\text { Sugar industry and starch } \\
\text { processing }\end{array}$ & Alqueres et al. (2007) \\
\hline $\begin{array}{l}\text { Thermococcus profundus } \\
\text { DT5432 }\end{array}$ & alpha-Amylases & Topt. $=80^{\circ} \mathrm{C}$ & $\begin{array}{l}\text { Sugar industry and starch } \\
\text { processing }\end{array}$ & $\begin{array}{l}\text { Eichler (2001), Antranikian } \\
\text { et al. (2005) }\end{array}$ \\
\hline Staphylothermus marines & Pullulanases & Topt. $=90-105^{\circ} \mathrm{C}$ & $\begin{array}{l}\text { Sugar industry and starch } \\
\text { processing }\end{array}$ & $\begin{array}{l}\text { Eichler (2001), Antranikian } \\
\text { et al. (2005) }\end{array}$ \\
\hline $\begin{array}{r}\text { Thermoplasma } \\
\text { acidophilum }\end{array}$ & Glucoamylases & Topt. $=90^{\circ} \mathrm{C}$ & $\begin{array}{l}\text { Sugar industry and starch } \\
\text { processing }\end{array}$ & $\begin{array}{l}\text { Eichler (2001), Antranikian } \\
\text { et al. (2005) }\end{array}$ \\
\hline Pyrococcus woesei & $\beta$-Galactosidases & Topt. $=93{ }^{\circ} \mathrm{C}$ & $\begin{array}{l}\text { Production of milk with low } \\
\text { lactose content }\end{array}$ & Dabrowski et al. (1998) \\
\hline $\begin{array}{l}\text { Pyrococcus furiosus } \\
\text { Sulfolobales sp. }\end{array}$ & Cellulases & Topt. $=103{ }^{\circ} \mathrm{C}$ & $\begin{array}{l}\text { Production of alcohol, fruit } \\
\text { industry }\end{array}$ & Antranikian et al. (2005) \\
\hline Pyrodictium abyssi & Xylanases & Topt. $=100-110^{\circ} \mathrm{C}$ & Paper industry-bleaching of pulp & $\begin{array}{l}\text { Egorova and Antranikian } \\
\text { (2005), Eichler (2001) }\end{array}$ \\
\hline $\begin{array}{l}\text { Humicola lanuginosa } \\
\text { strain Y-38 }\end{array}$ & Lipases & Topt. $=65^{\circ} \mathrm{C}$ & Laundry detergents & Arima et al. (1972) \\
\hline $\begin{array}{l}\text { Myceliophthora } \\
\text { thermophila }\end{array}$ & Laccases & Topt. $=60{ }^{\circ} \mathrm{C}$ & $\begin{array}{l}\text { Polymerization of phenolic } \\
\text { compounds to humic substances }\end{array}$ & Chefetz et al. (1998) \\
\hline $\begin{array}{c}\text { Myceliophthora } \\
\text { thermophila }\end{array}$ & Phytases & Topt. $=42-45{ }^{\circ} \mathrm{C}$ & Animal feed & Wyss et al. (1999) \\
\hline Penicillium duponti & $\begin{array}{l}\text { glucose-6-phosphate } \\
\text { dehydrogenase }\end{array}$ & Topt. $=50^{\circ} \mathrm{C}$ & $\begin{array}{l}\text { Generation of NADPH for } \\
\text { biosynthetic reactions }\end{array}$ & Broad and Shepherd (1970) \\
\hline Bacillus lichniformis & Alcalase & Topt. $=60{ }^{\circ} \mathrm{C}$ & $\begin{array}{l}\text { Component of protein-fortified soft } \\
\text { drinks and dietetic food, helps } \\
\text { in protein recovery from } \\
\text { meat, fish and crustacean } \\
\text { shell waste }\end{array}$ & Synowiecki (2008) \\
\hline
\end{tabular}

Table 2 Recent patents on thermophiles and their potential applications

\begin{tabular}{|c|c|c|c|c|}
\hline $\begin{array}{l}\text { S. } \\
\text { no }\end{array}$ & Topic & Patent number and date & Application & References \\
\hline 1 & $\begin{array}{l}\text { Single step bioconversion of } \\
\text { lignocellulosic biomass to } \\
\text { biofuels using extreme } \\
\text { thermophilic bacteria }\end{array}$ & $\begin{array}{l}\text { US2014/0363869 A1 December } \\
\text { 11, } 2014\end{array}$ & $\begin{array}{l}\text { Bioconversion of lignocellulosic } \\
\text { biomass to biofuels }\end{array}$ & Curvers et al. (2014) \\
\hline 2 & $\begin{array}{l}\text { Thermophilic bacterium and uses } \\
\text { of extracellular proteins } \\
\text { therefrom }\end{array}$ & $\begin{array}{l}\text { US } 8828238 \text { B2 September 9, } \\
2014\end{array}$ & Excellent metal ion binding ability & Han et al. (2014) \\
\hline 3 & $\begin{array}{l}\text { Fermentation of moderately } \\
\text { thermophilic Bacilli on sucrose }\end{array}$ & US 8,663,954 B2 March 4, 2014 & $\begin{array}{l}\text { Genetic modification of moderately } \\
\text { thermophilic Bacillus strain to } \\
\text { utilise sucrose as a carbon source }\end{array}$ & $\begin{array}{l}\text { Van Kranenburg et al. } \\
\text { (2014) }\end{array}$ \\
\hline 4 & $\begin{array}{l}\text { Bioremediation of persistent } \\
\text { organic pollutants using } \\
\text { thermophilic bacteria }\end{array}$ & $\begin{array}{l}\text { US 2014/0042087 A1 February } \\
\quad 13,2014\end{array}$ & Degradation of organic pollutants & O’Driscoll et al. (2014) \\
\hline 5 & $\begin{array}{l}\text { Phytase-producing bacteria, } \\
\text { phytase and production method } \\
\text { of phytase }\end{array}$ & $\begin{array}{l}\text { US 6,180,390 B1 January 30, } \\
2001\end{array}$ & $\begin{array}{l}\text { Role in animal feeding, environmental } \\
\text { protection, human nutrition and } \\
\text { health and industrial applications. }\end{array}$ & Chu et al. (2001) \\
\hline 6 & $\begin{array}{l}\text { Process for producing modified } \\
\text { microorganisms for oil } \\
\text { treatment at high temperatures, } \\
\text { pressures and salinity }\end{array}$ & $\begin{array}{l}\text { US 5492828A February 20, } \\
1996\end{array}$ & $\begin{array}{l}\text { Used in microbial enhanced oil } \\
\text { recovery }\end{array}$ & Eugene et al. (1996) \\
\hline
\end{tabular}


Fig. 1 Various applications of thermophilic microorganisms

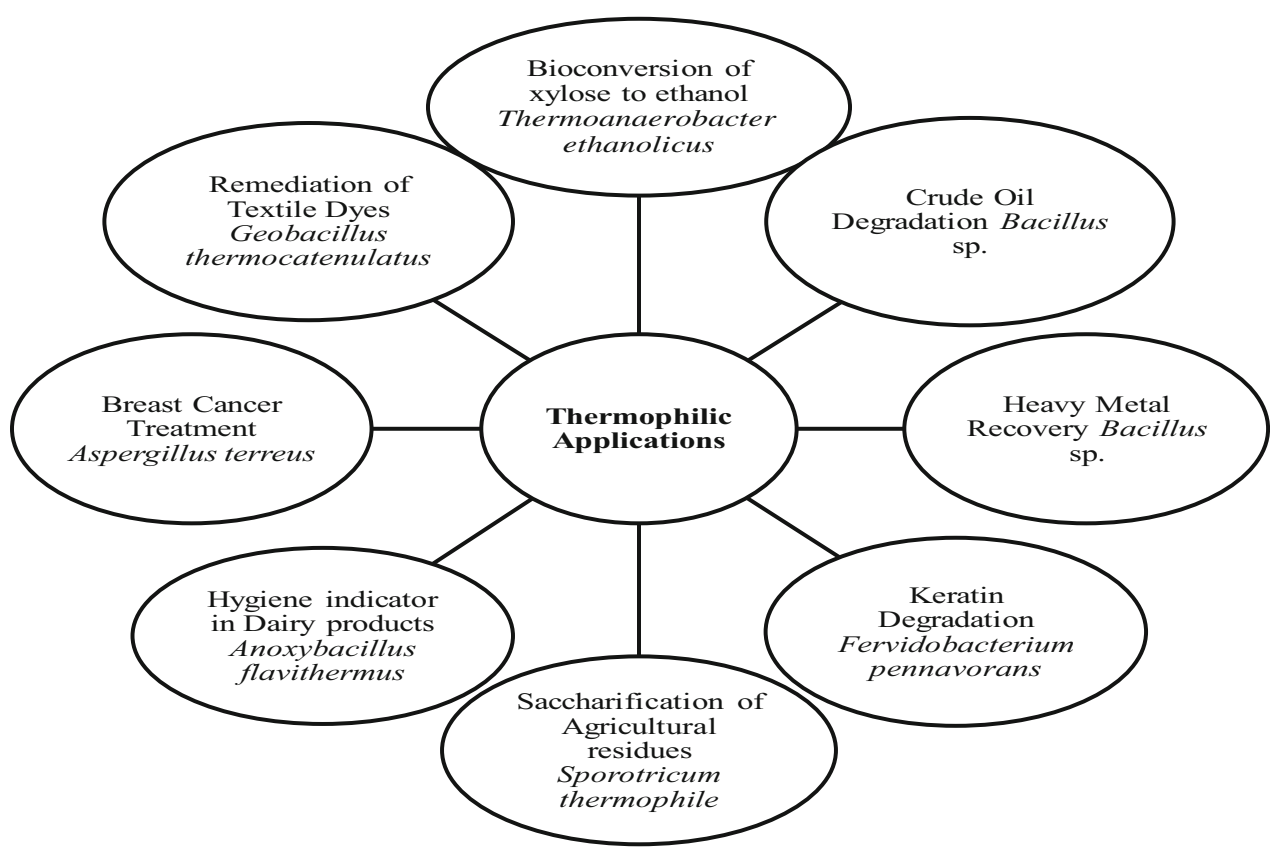

flow of low-molecular weight compounds. The permeability of fatty acyl ester lipid membranes is highly temperature dependent and their phase-transition temperature is dependent on the fatty acid composition, so when the growth temperature shifts, the fatty acid composition of membrane lipids is quickly regulated (Koga 2012).

2. Chemical stability: thermophilic organisms are able to grow at high temperature due to the chemical stability of their membrane lipids (Koga 2012).

3. Temperature: lipids that increase in proportion to an increase in growth temperature may be designated as "thermophilic lipids." In the extremely thermophilic environment, methanoarchaea Methanocaldococcus jannaschii have been reported. When the growth temperature increases from 45 to $65^{\circ} \mathrm{C}$, the diether lipids (archaeolbased lipids) decrease from 80 to $20 \%$, while the standard caldarchaeol-based and cyclic archaeol-based lipids increase from 10 to $40 \%$, respectively (Sprott et al. 1991).

4. G+C content: rRNA and tRNA molecules of thermophilic bacteria have higher $\mathrm{G}+\mathrm{C}$ contents than mesophiles (Galtier and Lobry 1997). Because the GC base pair forms more hydrogen bonds than the AT base pair, higher $\mathrm{G}+\mathrm{C}$ contents in the double-stranded stem region improves thermostability of the RNA molecules (Lao and Forsdyke 2000; Paz et al. 2004).

5. Proteins: the surface regions of thermophilic proteins have fewer (non-charged) polar amino acids and more charged amino acids, and these charged residues result in an increased number of intramolecular salt bridges (Thompson and Eisenberg 1999).

The ability of microorganisms to survive under harsh conditions has prompted researchers to study these organisms to better understand their characteristics and eventually utilize them in various applications. Further insight into thermophilic microorganisms has been highlighted through this review article as thermophiles possess enumerable properties suitable for biotechnological and commercial applications.

\section{Biotechnological applications of thermophiles}

Thermophiles have shown tremendous promise in terms of their applications in modern biotechnology. Some of the high end applications of these thermophiles have been elucidated below (Fig. 1).

\section{Bioconversion of lignocellulose to hydrogen}

Although many reported microorganisms possess the capability of cellulose hydrolysis or hydrogen production $\left(\mathrm{H}_{2}\right)$, no conclusive research has been able to clarify that both of these capabilities are possessed in a single microorganism. Hot springs are a potential source for thermophilic hydrogen $\left(\mathrm{H}_{2}\right)$ and ethanol producing microorganisms. Compared with mesophiles, thermophiles are thought to be more robust for cellulose degradation and hydrogen production. In particular, the rate of cellulolysis 
is presumably more rapid at elevated temperatures (Wiegel and Ljungdahl 1986; Blumer-Schuette et al. 2008). As a result, thermophilic microorganisms isolated from various environments are an attractive prospect for cellulolytic biohydrogen production (CBP) from complex lignocellulosic biomass. The co-cultures of thermophilic cellulolytic bacterium Clostridium thermocellum with non-cellulolytic thermophilic anaerobic bacteria and the extremely thermophilic cellulolytic bacterium Caldicellulosiruptor saccharolyticus have been used for CBP-based hydrogen production (Liu et al. 2008; Ivanova et al. 2009). Several species of genus Thermoanaerobacterium including $T$. thermosaccharolyticum, $T$. polysaccharolyticum, T. zeae, T. lactoethylicum, T. aotearoense, and T. saccharolyticum possess the capability to utilize various macromolecules accompanied by $\mathrm{H}_{2}$ production (Ganghofer et al. 1998; Hoster et al. 2001; O-Thong et al. 2008; Ren et al. 2008; Cann et al. 2001; Ueno et al. 2001).

Several anaerobic thermophiles have been shown to utilize cellulose, including Clostridium thermocellum, Clostridium straminisolvens, Clostridium stercorarium, Caldicellulosiruptor saccharolyticus, and Caldicellulosiruptor obsidiansis (Freier et al. 1988; Hamilton-Brehm et al. 2010; Kato et al. 2004; Madden 1983; Rainey et al. 1994; Wiegel and Dykstra 1984).

Hydrogen may be the fuel of the future once hydrogen fuel cells for propelling cars are perfected (McAlister 1998). When oxygen and hydrogen are combined in a fuel cell, they provide electricity and a little heat, giving water as the only waste product. The hydrogen car will be clean because it will not discharge nitrogen oxides and carbon dioxide. Hydrogen can be obtained cheaply using special enzymes (extremozymes) by the transformation of cellulose into glucose sugar, then converting the glucose product and its byproduct, gluconic acid into hydrogen (Woodward et al. 2000).

The extremely thermophilic bacterium $C$. owensensis has comprehensive hemicellulase and cellulase system. The enzymes of $C$. owensensis had high ability for degrading the hemicellulose of native lignocellulosic biomass. High temperature pre-hydrolysis on native lignocellulosic biomass by the extra-enzyme of $C$. owensensis could greatly improve the glucan conversion rate, making almost the same contribution as steam-exploded pretreatment (Peng et al. 2015).

\section{Conversion of glycerol to lactate}

Bioprospecting efforts for exploring novel biocatalytic molecules with unique properties have inspired the design and construction of a wider variety of artificial metabolic pathways (Bond-Watts et al. 2011). Employment of enzymes derived from thermophiles and hyperthermophiles enables the simple preparation of catalytic modules with excellent selectivity and thermal stability (Ye et al. 2012; Ninh et al. 2015). These excellent stabilities of thermophilic enzymes allow greater flexibility in the operational conditions of in vitro bioconversion systems. Generally, $10 \mathrm{~kg}$ of crude glycerol, which is the primary byproduct of the biodiesel industry, is released for every $100 \mathrm{~kg}$ of biodiesel and the growing production of biodiesel has resulted in a worldwide surplus of crude glycerol (Nguyen et al. 2013). An artificial in vitro metabolic pathway for the conversion of glycerol to lactate has been constructed. The in vitro pathway consisted of nine thermophilic and hyperthermophilic enzymes and designed to balance the intrapathway consumption and regeneration of cofactors (Okano et al. 2010).

\section{Conversion of D-xylose into ethanol}

Thermophilic anaerobic bacteria could be promising candidates for conversion of hemicellulose or its monomers (xylose, arabinose, mannose and galactose) into ethanol with a satisfactory yield and productivity. A number of thermophilic enrichment cultures, and new isolates of thermophilic anaerobic bacterial strains growing optimally at $70-80{ }^{\circ} \mathrm{C}$ for their ethanol production from D-xylose have been isolated from hot springs, paper pulp mills and brewery waste water. The species investigated so far are Thermoanaerobacter ethanolicus (Wiegel and Ljungdahl 1981; Kannan and Mutharasan 1985), Clostridium thermocellum (Viljoen et al. 1926; McBee 1954; $\mathrm{Ng}$ et al. 1981), Clostridium thermohydrosulfuricum (Cook and Morgan 1994; Wiegel et al. 1979; Dönmez and Özcelik 1992) (reclassified as Thermoanaerobacter thermohydrosulfuricus) (Lee et al. 1993), Thermoanaerobium brockii (Zeikus et al. 1979; Ben-Bassat et al. 1981) (reclassified as Thermoanaerobacter brockii) (Lee et al. 1993), Clostridium thermosaccharolyticum (McClung 1935; Mistry and Cooney 1989) (reclassified as Thermoanaerobacterium thermosaccharolyticum) (Collins et al. 1994) and Thermoanaerobacterium saccharolyticum B6A (Lee et al. 1993; Weimer 1985). To obtain a viable bio-ethanol production, all the carbohydrate constituents of lignocellulosic biomass need to be converted into ethanol (Wright 1988; Lynd 1990; Von Sivers and Zacchi 1995). Xylan is mainly composed of D-xylose and it has been reported that most of the isolates produced ethanol as the main end fermentation product from both xylose and xylan (Sommer et al. 2004). Among the advantages, thermophiles have broad substrate spectra and can degrade both hexoses and pentoses simultaneously; some thermophiles natively degrade complex carbohydrates; they operate at temperatures that minimize contamination risk of mesophiles. Additionally, recent advances have improved ethanol yields by using 
genetic engineering, often by knocking out metabolic pathways to other end products. This has minimized the perceived advantage of mesophiles over thermophiles considerably, although no large scale bioethanol plants with genetically modified microbes are currently operating (Scully and Orlygsson 2015).

\section{Biodegradation of petroleum hydrocarbons}

Thermophiles have also been utilized for the microbial degradation of crude oil and refined petroleum pollutants. Foght and McFarlane (1999) studied the growth of extremophiles on petroleum hydrocarbon. Some potential applications are related to molecular genetics of polycyclic aromatic hydrocarbon degradation by bacteria. Also the factors that control degradation and methods to enhance the ability of bacteria to degrade such pollutants in the environment have been studied. April et al. (2000) studied the process of crude oil degradation by mixed populations, pure cultures, and genetic mutants. They demonstrated the loss of parent compounds and analyzed the products of bacterial attack on crude oils using gas chromatography, mass spectrometry. The use of thermophiles for biodegradation of hydrocarbons with low water solubility is of interest, as solubility and bioavailability, are enhanced at elevated temperatures. Thermophiles, predominantly bacilli, possess a significant potential for the degradation of environmental pollutants, including all major classes. Indigenous thermophilic hydrocarbon degraders are of special significance for the bioremediation of oil-polluted desert soil (Margesin and Schinner 2001).

\section{Recovery of heavy metals}

As a result of increasing industrial activities, heavy metal contamination is a problem. Microorganisms can interact with heavy metals in a variety of ways that result in decreased metal mobility and solubility. The metal and sulfate-reducing bacteria have suitable physiology for metal precipitation and immobilization. The activities of these microbes provide metabolic products such as iron and hydrogen sulphide, which lead to mineral formation. These minerals can react with heavy metals, resulting in precipitation and hence detoxification (Chalaal and Islam 2001). In order to understand the removal of such types of toxins, Chalaal and Islam (2001) used two strains of thermophilic bacteria belonging to the Bacillus family, isolated from hot water stream, to remove strontium from aqueous stream systems. These bacteria were able to concentrate strontium in one side of a two-compartment bioreactor. Immobilization of heavy metals using sulphide-producing microorganisms has been reported as an effective means of treating some metal-contaminated sites (Crawford and Crawford 1996).

\section{Remediation of textile dyes}

Laccase enzyme purified from thermophile, Geobacillus thermocatenulatus MS5 is of very higher catalytic activity and are economic, highly stable at different temperatures and $\mathrm{pH}$ levels and can be used widely and effectively in the removal of the dyes that cause environmental pollution. Verma and Shirkot investigated the purified laccase enzyme for the removal of some dyes used in industry i.e., Remazole Brilliant Blue R (RBBR), Indigo carmine, Congo red, Brilliant green and Bromophenol blue. In case of Indigo carmine and congo red dye, $99 \%$ of decolorization occured after $48 \mathrm{~h}$ of incubation, followed by RBBR dye, Bromophenol Blue and Brilliant Green i.e., 98, 70 and $60 \%$ respectively (Verma and Shirkot 2014).

Thermophilic lignolytic fungal cultures were isolated from soil/digested slurry/plant debris and were subjected for acclimatization to Remazol Brilliant Blue (RBB) at $0.05 \%$ concentration, in the malt extract broth (MEB). The results suggested the isolates as a useful tool for degradation of reactive dyes (Sahni and Gupta 2014).

\section{Saccharification of agricultural residues}

Sporotricum thermophile LAR5 is an excellent fungal isolate having an ability to utilize crude agriculture based materials as carbon and nitrogen sources to produce significant cellulase titre. Cellulase possesses desirable properties from industrial application point of view such as activity and stability over broad $\mathrm{pH}$ range and high temperatures and good saccharification ability on acid-pretreated rice straw. It has been reported that considerable sugars are produced by enzymatic hydrolysis of acid-pretreated solids $(3.5,5.7,7.9,7.7$ micromoles $/ \mathrm{ml}$ from $1,3,5$ and $7 \%$ acid-pretreated solids, respectively) using the S. thermophile LAR5 cellulase (Bajaj et al. 2014). Recombinant $S$. thermophile cellulase shows potential to hydrolyze variety of cellulosic substrates with a peculiarity that presence of lignin in various substrates enhances the degree of saccharification (Dimarogona et al. 2012).

\section{Thermophilic bacilli in dairy processing}

Thermophilic bacilli are used as hygiene indicators of processed product, within the dairy processing context. This is because of the ability of these strains to form endospores and biofilms. The thermophilic bacilli, such as Anoxybacillus flavithermus and Geobacillus spp., are an important group of contaminants in the dairy industry. Although these bacilli are generally not pathogenic, their presence in dairy products is an indicator of poor hygiene and high numbers are unacceptable to customers. In addition, their growth may result in milk product defects caused by the production of acids or enzymes, potentially leading to off-flavors (Burgess

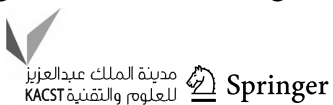


et al. 2010). Many strains of genera Lactobacillus and Bifidobacterium, as well as some enterococci and yeasts, have been shown to possess probiotic properties with potential for prophylaxis and treatment of a range of gastrointestinal disorders (Varankovich et al. 2015).

\section{Keratin degradation}

A novel thermophilic bacterium, Fervidobacterium pennavorans, belonging to the Thermotogales order, isolated from hot springs of Azores island, grows optimally at $70{ }^{\circ} \mathrm{C}$ and $\mathrm{pH}$ 6.5. It is the first known thermophile that is able to degrade native feathers at high temperatures. With the help of these enzymes, feathers could be converted to defined products such as the rare amino acids, serine, cysteine and proline (Friedrich and Antranikian 1996).

\section{Cancer treatment}

Asperjinone, a nor-neolignan, and Terrein, a suppressor of ABCG2-expressing breast cancer cells were isolated from thermophile Aspergillus terreus, which can restore drug sensitivity and could be the key to improve breast cancer therapeutics. Terrein, displayed strong cytotoxicity against breast cancer MCF-7 cells. Treatment with terrein significantly suppressed growth of ABCG2-expressing breast cancer cells. This suppressive effect was achieved by inducing apoptosis via activating the caspase-7 pathway and inhibiting the Akt signaling pathway, which led to a decrease in ABCG2-expressing cells and a reduction in the side-population phenotype (Liao et al. 2012). Conventional chemotherapeutic agents are usually non specific towards cancerous cells and inhibit the progression of any dividing cells. The therapeutic potential of antitumor drugs is seriously limited by the manifestation of serious side effects and drug resistance. So there is a need of agents that are more effective, more selective and may not cause drug resistance. According to Patent no. WO 2006/053445 A1, an invention is disclosed, whereby a composition of bacteriocin derived from lactic acid bacteria and a carrier can be used for inhibiting proliferation of cancerous cells (Mehta et al. 2013).

\section{Conclusions}

The increasing number of patents indicates that there is a growing interest in the commercial applications of thermophiles. The demand for thermostable enzymes has increased tremendously in the past few years. Since only a very few species from this group of microorganisms have been isolated till date, there seems to be a large number of hyperthermophilic catalysts with unique properties awaiting discovery.
Acknowledgments Authors would like to acknowledge M.M. University Mullana (Ambala) for providing all the requisite facilities pertaining to the said work.

\section{Compliance with ethical standards}

Conflict of interest There exists no conflict of interest regarding publication of this manuscript.

Open Access This article is distributed under the terms of the Creative Commons Attribution 4.0 International License (http:// creativecommons.org/licenses/by/4.0/), which permits unrestricted use, distribution, and reproduction in any medium, provided you give appropriate credit to the original author(s) and the source, provide a link to the Creative Commons license, and indicate if changes were made.

\section{References}

Alqueres SMC, Almeida RV, Clementino MM, Vieira RP, Almeida WI, Cardoso AM, Martins OB (2007) Exploring the biotechnological applications in the archeal domain. Brazil $\mathrm{J}$ Microbiol 38:398-405

Antranikian G, Vorgias CE, Bertoldo C (2005) Extreme environments as a resource for microorganisms and novel biocatalysts. Adv Biochem Eng Biotechnol 96:219-262

April TM, Foght JM, Currah RS (2000) Hydrocarbon-degrading fungi isolated from flare pit soils in northern and western Canada. Can J Microbiol 46:38-49

Arima K, Liu WH, Beppu T (1972) Studies on the lipase of thermophilic fungus Humicola lanuginosa. Agric Biol Chem 36:893-895

Bajaj BK, Sharma M, Rao RS (2014) Agricultural residues for production of cellulase from Sporotrichum thermophile LAR5 and its application for saccharification of rice straw. J Mater Environ Sci 5(5):1454-1460

Ben-Bassat A, Lamed R, Zeikus JG (1981) Ethanol production by thermophilic bacteria: metabolic control of end product formation in Thermoanaerobium brockii. J Bacteriol 146:192-199

Benignetm D (1905) Di un germe termofflo isolato dai fanghi d'Acqui. Riv d'igiene santa pubbl 16:449-455

Blau O (1906) Ueber die Temperaturmaxidma der Sporenkeimung und der Sporenbildung,sowie die supramaximalen Totungszeiten der Sporen der Bakterien, auch derjenigen mit hohen Temperaturmaxima Zentr Bakt Parasitenk Infek II 15:97-143

Blumer-Schuette SE, Kataeva I, Westpheling J, Adams MWW, Kelly RM (2008) Extremely thermophilic microorganisms for biomass conversion: status and prospects. Curr Opin Biotechnol 19:210-217

Bond-Watts BB, Bellerose RJ, Chang MCY (2011) Enzyme mechanism as a kinetic control element for designing synthetic biofuel pathways. Nat Chem Biol 7:222-227

Broad TE, Shepherd MG (1970) Purification and properties of glucose-6-phosphate dehydrogenase from the thermophilic fungus Penicillium duponti. Biochim Biophys Acta 198:407-414

Burgess SA, Lindsay D, Flint SH (2010) Thermophilic bacilli and their importance in dairy processing. Int $\mathrm{J}$ Food Microbiol 144:215-225

Cann IKO, Stroot PG, Mackie KR, White BA, Mackie RI (2001) Characterization of two novel saccharolytic, anaerobic thermophiles, Thermoanaerobacterium polysaccharolyticum sp. nov and Thermoanaerobacterium zeae sp. nov, and emendation of the genus Thermoanaerobacterium. Int J Syst Evol Microbiol 51:293-302 
Catterina G (1904) Beitrag zum Studium der thermophilen Bakterien. Zentr Bakt Parasitenk Infek Il 12:353-355

Chalaal O, Islam MR (2001) Integrated management of radioactive strontium contamination in aqueous stream systems. J Environ Manage 61:51-59

Chefetz B, Chen Y, Hadar Y (1998) Purification and characterization of laccase from Chaetomium thermophilium and its role in humification. Appl Environ Microbiol 64:3175-3179

Chu JS, Chung SF, Tseng M, Wen CY, Chu WS (2001) Phytaseproducing bacteria, phytase and production method of phytase. US 6,180,390 B1

Collins MD, Lawson PA, Willems A, Cordoba JJ, FernandezGarayzabal J, Garcia P, Cai J, Hippe H, Farrow AE (1994) The phylogeny of the genus Clostridium: proposal of five new genera and eleven new species combinations. Int $J$ Syst Bacteriol 44:812-826

Cook GM, Morgan HW (1994) Hyperbolic growth of Thermoanaerobacter thermohydrosulfuricus (Clostridium thermohydrosulfuricus) increases ethanol production in $\mathrm{pH}$ controlled batch culture. Appl Microbiol Biotechnol 41:84-89

Crawford RL, Crawford DL (1996) Bioremediation: principles and applications. Cambridge: Cambridge University Press

Curvers S, Koln DE, Svetlichnyi V (2014) Single step bioconversion of lignocellulosic biomass to biofuels using extreme thermophilic bacteria. US Patent 0363869 A1

Dabrowski S, Maciuńska J, Synowiecki J (1998) Cloning and nucleotide sequence of the thermostable beta-galactosidase gene from Pyrococcus woesei in Escherichia coli and some properties of the isolated enzyme. Mol Biotechnol 10(3):217-222

De kruyff E (1910) Les bact6ries thermophiles dans le tropiques Zentr Bakt Parasitenk Infek II 26:65-74

Dimarogona M, Topakas E, Olsson L, Christakopoulos P (2012) Lignin boosts the cellulase performance of a GH-61 enzyme from Sporotrichum thermophile. Bioresour Technol 110:480-487

Dö nmez S, Ö zcelik F (1992) Ethanol fermentation of beet molasses by Clostridium thermohydrosulfuricam. Enzyme Microb Tech $14: 413-416$

Egorova K, Antranikian G (2005) Industrial revelance of thermophilic. Archaea Curr Opin Microbiol 8:649-655

Eichler J (2001) Biotechnological uses of archaeal extremozymes. Biotech Adv 19:261-278

Eugene T, Premuzic EM, Lin M, Point R (1996) Process for producing modified microorganisms for oil treatment at high temperatures, pressures and salinity. US 005,492,828A

Falcioni D (1907) I germi termofili nelle acque del Bullicame. Arch Farmacol Speri 6:1-5

Foght JM, McFarlane DM (1999) Growth of extremophiles on petroleum. In: Seckbach J (ed) Enigmatic microorganisms and life in extreme environments. Kluwer Academic Publishers, Dordrecht, pp 527-538

Freier D, Mothershed CP, Wiegel J (1988) Characterization of Clostridium thermocellum JW20. Appl Environ Microbiol 54:204-211

Friedrich AB, Antranikian G (1996) Keratin degradation by Fervidobacterium pennavorans, a novel thermophilic anaerobic species of the order Thermotogales. Appl Environ Microbiol 62(8):2875-2882

Galtier N, Lobry JR (1997) Relationships between genomic G+C content, RNA secondary structures, and optimal growth temperature in prokaryotes. J Mol Evol 44(6):632-636

Ganghofer D, Kellermann J, Staudenbauer WL, Bronnenmeier K (1998) Purification and properties of an amylopullulanase, a glucoamylase, and an alphaglucosidase in the amylolytic enzyme system of Thermoanaerobacterium thermosaccharolyticum. Biosci Biotech Bioch 62:302-308
Georgevitch P (1910a) Bacillus thermophilus Jivoini nov spec and Bacillus thermophilus Losanitchi nov spec Zentr Bakt Parasitenk Infek II 27:150-167

Georgevitch P (1910b) Bacillus thermophilus vranjensis. Arch Hyg Sci 72:201-210

Gilbert (1904) Ueber Actinomyces thermophilue und andere Aktinomyceten. Z Hyg Infektionskrankh 47:383-405

Golikowa SM (1926) Zur Frage der Thermobiose Zentr Bakt Parasitenk Infek II. 69:178-185

Haki GD, Rakshit SK (2003) Developments in industrially important thermostable enzymes. Bioresour Technol 89:17-34

Hamilton-Brehm SD, Mosher JJ, Vishnivetskaya T, Podar M, Carroll S, Allman S, Phelps TJ, Keller M (2010) Caldicellulosiruptor obsidiansis sp nov, an anaerobic, extremely thermophilic, cellulolytic bacterium isolated from Obsidian Pool, Yellowstone National Park. Appl Environ Microbiol 76:1014-1020

Han YL, Tainam TW, Guo TR, Zhubei TW, Chang JS, Taichung TW, Chou IJ (2014) Thermophilic bacterium and uses of extracellular proteins therefrom. US 8828238 B2

Hoster F, Daniel R, Gottschalk G (2001) Isolation of a new Thermoanaerobacterium thermosaccharolyticum strain (FH1) producing a thermostable dextranase. J Gen Appl Microbiol 47:187-192

Ivanova G, Rákhely G, Kovács KL (2009) Thermophilic biohydrogen production from energy plants by Caldicellulosiruptor saccharolyticus and comparison with related studies. Int J Hydrogen Energ 34:3659-3670

Kannan V, Mutharasan R (1985) Ethanol fermentation characteristics of Thermoanaerobacter ethanolicus. Enzyme Microb Technol $7: 87-89$

Kato S, Haruta S, Cui ZJ, Ishii M, Yokota A, Igarashi Y (2004) Clostridium straminisolvens sp nov, a moderately thermophilic, aerotolerant and cellulolytic bacterium isolated from a cellulosedegrading bacterial community. Int $\mathrm{J}$ Syst Evol Microbiol 54:2043-2047

Koga Y (2012) Thermal adaptation of the archaeal and bacterial lipid membranes. Archaea 2012:6

Kranenburg RV, Wageningen NL, Hartskamp MV, Gorinchem NL (2014) Fermentation of moderately thermophilic bacilli on sucrose. US 8,663,954 B2

Lao PJ, Forsdyke DR (2000) Thermophilic bacteria strictly obey Szybalski's transcription direction rule and politely purine-load RNAs with both adenine and guanine. Genome Res 10(2):228-236

Lee Y, Jain MK, Lee C, Lowe SE, Zeikus JG (1993) Taxonomic distinction of saccharolytic thermophilic anaerobes: description of Thermoanaerobacterium xylanolyticum gen nov, sp nov, and Thermoanaerobacterium saccharolyticum gen nov, sp nov; reclassification of Thermoanaerobium brockii, Clostridium thermosulfurigenes and Clostridium thermohydrosulfuricum E10069 as Thermoanaerobacter brockii comb nov, Thermoanaerobacterium thermosulfurigenes comb nov, and Thermoanaerobacter thermohydrosulfuricus comb nov, respectively; and transfer of Clostridium thermohydrosulfuricum 39E to Thermoanaerobacter ethanolicus. Int J Syst Bacteriol 43:41-51

Liao WY, Shen CN, Lin LH, Yang YL, Han HY, Chen JW, Kuo SC, Wu SH, Liaw CC (2012) Asperjinone, a nor-neolignan, and terrein, a suppressor of ABCG2-expressing breast cancer cells, from thermophilic Aspergillus terreus. J Nat Prod 75(4):630-635

Liu Y, Yu P, Song X, Qu YB (2008) Hydrogen production from cellulose by coculture of Clostridium thermocellum JN4 and Thermoanaerobacterium thermosaccharolyticum GD17. Int J Hydrogen Energ 33:2927-2933

Lynd LR (1990) Large scale fuel ethanol from lignocellulose: potential, economics, and research priorities. Appl Biochem Biotechnol 24(25):695-720

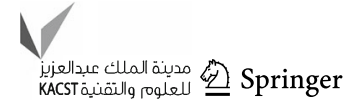


MacFadyen A and Blaxall FR (1896) Thermophilic bacteria. J Path Bact 3:87-99; Brit Med J 2, 644

Madden RH (1983) Isolation and characterization of Clostridium stercorarium sp nov, cellulolytic thermophile. Int J Syst Bacteriol 33:837-840

Margesin R, Schinner F (2001) Biodegradation and bioremediation of hydrocarbons in extreme environments. Appl Microbiol Biotechnol 56:650-663

McAlister R (1998) Manufacturing sustainable prosperity in hydrogen today. Am Hydrogen Assoc 8(1):1-34

McBee RH (1954) The characteristics of Clostridium thermocellum. J Bacteriol 67:505-506

McClung LS (1935) Studies on anaerobic bacteria: IV taxonomy of cultures of a thermophilic species causing "swells" of canned foods. J Bacteriol 29:189-202

Mehta R, Arya R, Goyal K, Singh M, Sharma AK (2013) Biopreservative and therapeutic potential of pediocin: recent trends and future perspectives. Recent Pat Biotechnol 7:172-178

Mistry FR, Cooney CL (1989) Production of ethanol by Clostridium thermosaccharolyticum: I effect of cell recycle and environmental parameters. Biotechnol Bioeng 34:1295-1304

Negre L (1913) Bacteries thermophiles des sables du Sahara. C R Biol 74:814-816

Ng TK, Ben-Bassat A, Zeikus JG (1981) Ethanol production by thermophilic bacteria: fermentation of cellulosic substrates by cocultures of Clostridium thermocellum and Clostridium thermohydrosulfuricum. Appl Environ Microbiol 41:1337-1343

Nguyen AQ, Kim YG, Kim SB, Kim CJ (2013) Improved tolerance of recombinant Escherichia coli to the toxicity of crude glycerol by overexpressing trehalose biosynthetic genes (otsBA) for the production of $\beta$-carotene. Biores Technol 143:531-537

Ninh PH, Honda K, Sakai T, Okano K, Ohtake H (2015) Assembly and multiple gene expression of thermophilic enzymes in Escherichia coli for in vitro metabolic engineering. Biotechnol Bioeng 112:189-196

O’Driscoll K, Princeton NJ, Sambrotto R, Blauvelt NY, DiFilippo R, West Chester PA, Piccillo P, Chapel Hill NC (2014) Bioremediation of persistent organic pollutants using thermophilic bacteria. US 2014/0042087 A1

Okano K, Tanaka T, Ogino C, Fukuda H, Kondo A (2010) Biotechnological production of enantiomeric pure lactic acid from renewable resources: recent achievements, perspectives, and limits. Appl Microbiol Biotechnol 85:413-423

Oshima T, Moriya T (2008) A preliminary analysis of microbial and biochemical properties of high-temperature compost. Ann N Y Acad Sci 1125:338-344

O-Thong S, Prasertsan P, Karakashev D, Angelidaki I (2008) Thermophilic fermentative hydrogen production by the newly isolated Thermoanaerobacterium thermosaccharolyticum PSU2. Int J Hydrogen Energy 33:1204-1214

Paz A, Mester D, Baca I, Nevo E, Korol A (2004) Adaptive role of increased frequency of polypurine tracts in mRNA sequences of thermophilic prokaryotes. Proc Natl Acad Sci USA 101(9):2951-2956

Peng X, QiaoW Mi S, Jia X, Su H, Han Y (2015) Characterization of hemicellulase and cellulase from the extremely thermophilic bacterium Caldicellulosiruptor owensensis and their potential application for bioconversion of lignocellulosic biomass without pretreatment. Biotechnol Biofuels 8(131):1-14

Rainey FA, Donnison AM, Jansen PH, Saul D, Rodrigo A (1994) Description of Caldicellulosiruptor saccharolyticus gen nov, sp nov: an obligately anaerobic, extremely thermophilic, cellulolytic bacterium. FEMS Microbiol Lett 120:263-266

Ren NQ, Cao GL, Wang AJ, Lee DJ, Guo WQ, Zhu YH (2008) Dark fermentation of xylose and glucose mix using isolated Thermoanaerobacterium thermosaccharolyticum W16. Int J Hydrogen Energy 33:6124-6132
Sahni N, Gupta U (2014) Bio-degradation of synthetic textile dyes by thermophilic lignolytic fungal isolates. J Adv Lab Res Biol 5(4):137-139

Sames T (1900) Zur Kenntniss der bei hoherer Temperatur wachsenden Bakterienund Streptothrixarten. Z Hyg Infektionskrankh 33:313-362

Santos H, Da Costa MS (2002) Compatible solutes of organisms that live in hot saline environments. Environ Microbiol 4:501-509

Scully SM, Orlygsson J (2015) Recent advances in second generation ethanol production by thermophilic bacteria. Energies 8(1):1-30. doi: $10.3390 / \mathrm{en} 8010001$

Setchell WA (1903) The upper temperature limits of life. Science 17:934-937

Sommer P, Georgieva T, Ahring BK (2004) Potential for using thermophilic anaerobic bacteria for bioethanol production from hemicelluloses. Biochem Soc Trans 32(2):283-289

Sprott GD, Meloche M, Richards JC (1991) Proportions of diether, macrocyclic diether, and tetraether lipids in Methanococcus jannaschii grown at different temperatures. J Bacteriol 173(12):3907-3910

Synowiecki J (2008) Thermostable enzymes in food processing, in recent research developments in food biotechnology enzymes as additives or processing aids. Research Signpost, Kerala

Thompson MJ, Eisenberg D (1999) Transproteomic evidence of a loop-deletion mechanism for enhancing protein thermostability. J Mol Biol 290(2):595-604

Tirelli E (1907) I termofili delle acque potabili Zentr Bakt Parasitenk Infek II 19:328

Ueno Y, Haruta S, Igarashi Y (2001) Microbial community in anaerobic hydrogen producing microflora enriched from sludge compost. Appl Microbiol Biotechnol 57:555-562

Varankovich NV, Nickerson MT, Korber DR (2015) Probiotic-based strategies for therapeutic and prophylactic use against multiple gastrointestinal diseases. Front Biotechnol 6:1-14

Verma A, Shirkot P (2014) Purification and characterization of thermostable laccase from thermophilic Geobacillus thermocatenulatus MS5 and its applications in removal of textile dyes. Scholars Acad J Biosci 2(8):479-485

Viljoen JA, Fred EB, Peterson WH (1926) The fermentation of cellulose by thermophilic bacteria. J Agric Sci 16:1-17

Von Sivers M, Zacchi G (1995) A techno-economical comparison of three processes for the production of ethanol from wood. Biores Technol 51:43-52

Weimer PJ (1985) Thermophilic anaerobic fermentation of hemicellulose and hemicellulose-derived aldose sugars by Thermoanaerobacter strain B6A. Archives Microbiol 143:130-136

Wiegel J, Dykstra M (1984) Clostridium thermocellum: adhesion and sporulation while adhered to cellulose and hemicellulose. Appl Microbiol Biotechnol 20:59-65

Wiegel J, Ljungdahl LG (1981) Thermoanaerobacter ethanolicus gen nov, spec nov, a new, extreme thermophilic, anaerobic bacterium. Arch Microbiol 128:343-348

Wiegel J, Ljungdahl LG (1986) The importance of thermophilic bacteria in biotechnology. Crit Rev Biotechnol 3:39-108

Wiegel J, Ljungdahl LG, Rawson JR (1979) Isolation from soil and properties of the extreme thermophile Clostridium thermohydrosulfuricum. J Bacteriol 139:800-810

Woodward J, Orr M, Cordray K, Greenbaum E (2000) Biotechnology: enzymatic production of biohydrogen. Nature 405:1014-1015

Wright JD (1988) Ethanol from biomass by enzymatic hydrolysis. Chem Eng Prog 84(8):62-74

Wyss M, Brugger R, Kronenberger A, Rémy R, Fimbel R, Osterhelt G, Lehmann M, Van Loon APGM (1999) Biochemical characterization of fungal phytases (myo-inositol hexakisphosphate phosphohydrolase): catalytic properties. Appl Environ Microbiol 65:367-373 
Ye X, Honda K, Sakai T, Okano K, Omasa T, Hirota R, Kuroda A, Ohtake H (2012) Synthetic metabolic engineering-a novel, simple technology for designing a chimeric metabolic pathway. Microb Cell Fact 11:120-131
Zeikus JG, Hegge PW, Anderson MA (1979) Thermoanaerobacter brockii gen nov and sp nov, a new chemoorganotrophic, caldoactive, anaerobic bacterium. Arch Microbiol 122:41-48 